\title{
Why Did the EM Study Abroad Program Become one of the Most Popular on Campus?
}

\section{Dr. Kate D. Abel, Stevens Institute of Technology (SES)}

Kate Abel serves as the as the Director of the Bachelor of Engineering in Engineering Management Program in the School of Systems and Enterprises at Stevens Institute of Technology. She holds a Ph.D. in Technology Management and Applied Psychology. She has held several professional service positions including the President of the Engineering Management Division of the American Society for Engineering Education and the President of Epsilon Mu Eta, the Engineering Management Honor Society. She teaches courses in Total Quality Management, Engineering Economics, Entrepreneurial Analysis of Engineering Design, Statistics for Engineering Managers, Management of Engineering and Technology, and Senior Design. Her research areas include knowledge engineering, as well as, knowledge and information management. She has been published several times including chapters in the books Eshbach's Handbook of Engineering Fundamentals and Engineering Economic Analysis; in journals such as the Engineering Management Journal and the Journal of Engineering Education; and several conference proceedings. She is a member of the Board of Advisors at West Point for the Department of Systems Engineering. She is also a member of several professional societies including ASEE, ASEM, ASME, and EMH.

\section{Mr. Eric Specking, University of Arkansas}

Eric Specking serves as the Director of Undergraduate Recruitment for the College of Engineering at the University of Arkansas. He directs the engineering recruitment office and most of the College of Engineering's K-12 outreach programs. He received a B.S. in Computer Engineering and a M.S. in Industrial Engineering from the University of Arkansas. 


\title{
Why Did the EM Study Abroad Program Become one of the Most Popular on Campus?
}

\begin{abstract}
Traditionally, less than 1\% of all American college students in any degree level study abroad, but study abroad became very popular at Stevens Institute of Technology in 2013..$^{5}$ In 2013, the Engineering Management Program at Stevens instituted a new study abroad program which was reported about generally in an article presented at the 2013 ASEE Conference ${ }^{9}$. The Engineering Management Study Abroad program consisted of a two-week intensive Stevens course, taught by a Stevens professor in Italy. To further enhance the experience, students from the University of Mexico, Guadalajara and the University of Naples also participated in the 2013 course. It ended up being one of the most popular study abroad program in Stevens's history. It is the intent of the Engineering Management program at Stevens to run the course again in 2014. The proposed study for this article is to survey the applicants of the 2013 and 2014 Engineering Management study abroad program to determine what it is about this particular course and program that has spurred such interest and desire on the part of the students to suddenly participate in study abroad. The goal of the study would be to gain knowledge about these factors in order to be able to duplicate the situation for other study abroad opportunities at Stevens, and perhaps elsewhere.
\end{abstract}

\section{Introduction}

Study abroad is espoused as something that will improve the quality of a student's education. Many in the study abroad field feel strongly that it greatly impacts not only a student's education, but also the student's life. But the long-term benefits were mostly qualitative and subjective. In 2012, that changed when Dwyer and Peters working for the Institute for the International Education of Students completed the first large-scale survey exploring the long-term impact of study abroad. They analyzed data from over 3,400 respondents and found that study abroad is a defining moment in a student's life and has a lifelong impact on personal growth, intercultural development, as well as educational and career attainment ${ }^{2}$.

Goodman also from the Institute of International Education (IIE) says that beyond this, study abroad also cultivates global leaders ${ }^{4}$. Goodman gives examples of this with the Boren Award and Fulbright Program; both of which acknowledge study abroad participants. Alumni of the Boren Award, which is sponsored by the National Security Education Program and administered by IIE, have risen to leadership roles in the federal government. While many Fulbright alumni are ambassadors, members of congress, judges, university presidents, and over 40 have won the Nobel Prize for ideas and research they started while studying abroad.

There are other benefits to study abroad both in and outside of the classroom since every interaction is an opportunity to learn. Of course weekend trips to cultural sites and museums can add to learning. But even more mundane activities like grocery shopping can become an educational adventure. Simply being immersed in a culture truly helps to solidify the learning of a language and a different way of living. So by studying abroad 
one is broadening their own perspective of the world. Additionally, graduate schools and employers look favorably upon study abroad on a resume.

Moreover, the National Academy of Engineering on Educating the Engineer of 2020 calls for tomorrow's engineers to be able to live, learn, and understand other cultures and environments. ${ }^{7}$ ABET outcome h calls for engineers to have a "broad education necessary to understand other cultures and environments". 3

\section{The Need}

Given all the benefits of study abroad, and the calls by ABET, NAE, employers, and others to have students participate in study abroad, one would think that most students would study abroad. But the fact is less than $15 \%$ of students working toward a bachelors degree study abroad. ${ }^{4}$ And only 4-5 percent of those are undergraduate engineers. ${ }^{5}$ Engineers, more likely than other majors, will work for an organization with some part of their manufacturing or supply chain oversees. As engineers they will be more interrelated to this overseas connection. But if study abroad is something very few engineers undertake, how will the engineers of the future be prepared to think and work in this global marketplace?

When investigating the reasons few engineers study abroad, several themes emerge. First, engineering rarely requires the study of a foreign language. This would limit engineers to study abroad in English speaking countries, or severely limit study abroad opportunities to countries whose language is already spoken in the home.

Second, engineers typically have very technically specific courses. Finding these specialized courses at foreign universities is difficult, and at non-technical universities almost impossible.

Thirdly, students generally have a skewed idea of how much time or money might be required to participate in study abroad. As such they may not even consider study abroad as an option to their otherwise very full academic requirements.

So when the Engineering Management Department at Stevens designed a brand new study abroad opportunity for engineers, it took great pains to set it up in a way that research showed was positive from the view of the student. Much of the information was gathered and analyzed through previous research published with ASEE in 2013. ${ }^{9}$ Historically at Stevens, between 2008 and 2012, a total of only 30-40 students participated in varied study abroad events each year. When the Engineering Management program rolled out it's 2013 TG 421- Italy offering, it was at capacity within two weeks, with a waiting list. Although there were only 16 available slots in the Italy class, almost 30 Stevens's students applied to attend. That is the same number as ALL of the students that would normally study abroad at Stevens in an average year. Why did study abroad suddenly become so popular at Stevens? What was it about this particular program that propelled it to be the most sought after study abroad program in Stevens's recent history? Determining that was the purpose of this research. 


\section{Population}

The Engineering Management Program discussed herein is housed in the School of Systems and Enterprises at Stevens Institute of Technology, a small, private, urban campus across the Hudson River from Manhattan in New Jersey. Approximately 3000 undergraduate students are enrolled, the majority of whom are engineering students.

The 2013 study abroad program at Stevens was so successful that the University of Arkansas was invited to participate. The University of Arkansas is a large, public, rural University with around 25000 students and over 2900 undergraduate engineering students. The College of Engineering is $19 \%$ female and $20 \%$ ethnic minority.

\section{The Survey}

The survey consisted of six identification questions, four blocks of six to ten questions on importance and an open response question as seen below. This tool was modeled by culminating the results of Vistawide, Dwyer and Peters, SIT Study Abroad, Northwestern University, and Berdan. 1,2, 8, 10 The complete survey is below.

Q1. What Institution do you attend?

Q2. What is your classification?

Q3. What department are you a part of?

Q4. Are you a member of the Honors College (UofA Students)/Honors or Scholars Programs (Stevens)?

Q5. Gender

Q6. Is this your first overseas experience?

Q7. In the below table (table 1), please indicate the significance of each reason related to your personal growth in relation to why you chose to apply for the Stevens/UofA 2 week Study Abroad opportunity in Italy.

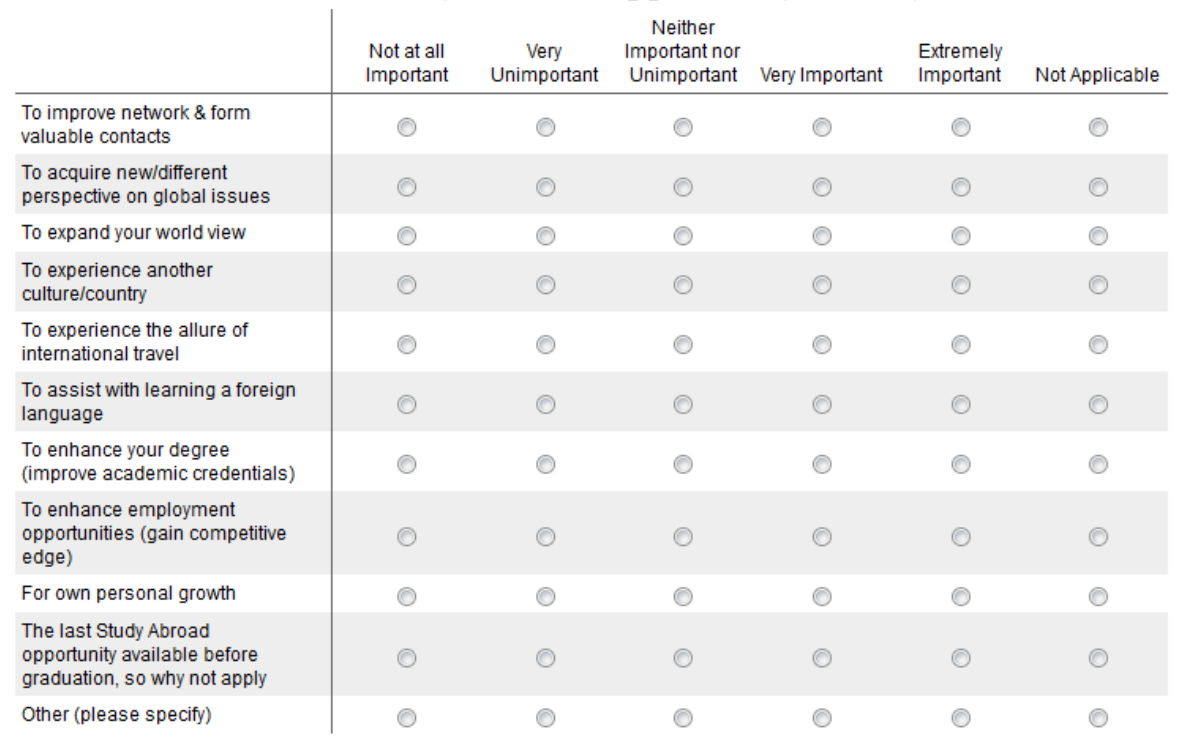

Table 1: Personal growth 
Q8. In the below table (table 2), please indicate the significance of each reason why you chose to apply for the Stevens/UofA 2 week Study Abroad opportunity in Italy.

\begin{tabular}{|c|c|c|c|c|c|c|}
\hline & $\begin{array}{l}\text { Not at all } \\
\text { Important }\end{array}$ & $\begin{array}{c}\text { Very } \\
\text { Unimportant }\end{array}$ & $\begin{array}{c}\text { Neither } \\
\text { Important nor } \\
\text { Unimportant }\end{array}$ & Very Important & $\begin{array}{l}\text { Extremely } \\
\text { Important }\end{array}$ & Not Applicable \\
\hline $\begin{array}{l}\text { Ease of not having to find your } \\
\text { own study abroad opportunity }\end{array}$ & 0 & 0 & 0 & 0 & 0 & 0 \\
\hline $\begin{array}{l}\text { Ease in signing up, registering, } \\
\text { enrolling }\end{array}$ & 0 & 0 & 0 & 0 & 0 & 0 \\
\hline $\begin{array}{l}\text { Monetary aspects were } \\
\text { easyleasier than other } \\
\text { opportunities }\end{array}$ & O & 0 & 0 & O & O & 0 \\
\hline $\begin{array}{l}\text { Dates of the trip were } \\
\text { convenient/ more convenient } \\
\text { than others }\end{array}$ & ○ & ○ & 0 & ○ & 0 & 0 \\
\hline $\begin{array}{l}\text { Ease of knowing the course } \\
\text { was already accepted as } \\
\text { Stevens/UofA credit }\end{array}$ & O & 0 & 0 & O & O & 0 \\
\hline $\begin{array}{l}\text { Ease of traveling with a group } \\
\text { (i.e. not alone) }\end{array}$ & 0 & 0 & 0 & 0 & 0 & 0 \\
\hline $\begin{array}{l}\text { Ease of staying in a hotel with } \\
\text { others you know }\end{array}$ & 0 & 0 & 0 & 0 & 0 & 0 \\
\hline $\begin{array}{l}\text { Ease of taking a class in } \\
\text { English as a study abroad } \\
\text { option }\end{array}$ & O & 0 & O & 0 & 0 & 0 \\
\hline Other (please specify) & ○ & $\odot$ & ○ & 0 & 0 & O \\
\hline
\end{tabular}

Table 2: Ease of being part of Italy program

Q9. In the below table (table 3), please indicate the most important thing you hope to gain from a study abroad experience.

\begin{tabular}{|c|c|c|c|c|c|c|}
\hline & $\begin{array}{l}\text { Not at all } \\
\text { Important }\end{array}$ & $\begin{array}{c}\text { Very } \\
\text { Unimportant }\end{array}$ & $\begin{array}{c}\text { Neither } \\
\text { Important nor } \\
\text { Unimportant }\end{array}$ & Very Important & $\begin{array}{l}\text { Extremely } \\
\text { Important }\end{array}$ & Not Applicable \\
\hline $\begin{array}{l}\text { Creative problem solving } \\
\text { experience }\end{array}$ & ○ & O & O & 0 & ○ & ○ \\
\hline $\begin{array}{l}\text { Self confidence/personal } \\
\text { growth }\end{array}$ & ○ & ○ & ○ & ○ & ○ & ○ \\
\hline $\begin{array}{l}\text { Getting more comfortable with } \\
\text { unfamiliar situations }\end{array}$ & ○ & O & ○ & O & O & ○ \\
\hline $\begin{array}{l}\text { Adaptability in culturally diverse } \\
\text { environments }\end{array}$ & ○ & ○ & ○ & ○ & ○ & ○ \\
\hline $\begin{array}{l}\text { Awareness of global } \\
\text { economies }\end{array}$ & ○ & ○ & ○ & ○ & ○ & ○ \\
\hline Improved communication skills & ○ & ○ & O & O & O & O \\
\hline $\begin{array}{l}\text { Long lasting international } \\
\text { friendships/contacts/network }\end{array}$ & ○ & ○ & ○ & ○ & ○ & ○ \\
\hline $\begin{array}{l}\text { Simple knowledge of another } \\
\text { culture/language }\end{array}$ & ○ & ○ & ○ & ○ & ○ & $\odot$ \\
\hline Other (please specify) & ○ & ○ & ○ & ○ & 0 & ○ \\
\hline
\end{tabular}

Table 3: Hope to gain from study abroad

Q10. In the below table (table 4), please indicate if the dates of the Stevens/UofA 2 week Study Abroad opportunity in Italy worked for your schedule. 


\begin{tabular}{|c|c|c|c|c|c|c|}
\hline & $\begin{array}{l}\text { Not at all } \\
\text { Important }\end{array}$ & $\begin{array}{c}\text { Very } \\
\text { Unimportant }\end{array}$ & $\begin{array}{c}\text { Neither } \\
\text { Important nor } \\
\text { Unimportant }\end{array}$ & Very Important & $\begin{array}{l}\text { Extremely } \\
\text { Important }\end{array}$ & Not Applicable \\
\hline $\begin{array}{l}\text { Dates of the trip allowed me to } \\
\text { be with my family the remainder } \\
\text { of the summer }\end{array}$ & ○ & O & ○ & 0 & ○ & 0 \\
\hline $\begin{array}{l}\text { Dates of the trip allowed me to } \\
\text { work the rest of the summer }\end{array}$ & ○ & O & ○ & ○ & ○ & ○ \\
\hline $\begin{array}{l}\text { Dates of the trip allowed me to } \\
\text { take other classes the } \\
\text { remainder of the summer }\end{array}$ & ○ & O & ○ & ○ & ○ & ○ \\
\hline $\begin{array}{l}\text { Dates of the trip allowed me to } \\
\text { travel the rest of the summer }\end{array}$ & ○ & 0 & 0 & 0 & 0 & 0 \\
\hline $\begin{array}{l}\text { Dates of the trip played no role } \\
\text { in wanting to attend TG } 421 \text {-Italy }\end{array}$ & ○ & O & ○ & ○ & O & O \\
\hline Other (please specify) & O & ○ & ○ & O & O & O \\
\hline
\end{tabular}

Table 4: Timing of program

Q11. What was the main reason you chose the Stevens/UofA 2 week study abroad program in Italy over other study abroad experiences?

\section{Methodology and Hypothesis}

Research showed that many study abroad supporters were in general agreement as to what students gain by study abroad. ${ }^{1,2,8}$ Learning a language, improving personal networks, expanding world view, enhancing education and employment opportunities were the major reasons behind a student's desire to study abroad. However, the authors hypothesized that there might be something else specific to the Italy study abroad opportunity that made it more desirable than other study abroad opportunities. To investigate this, a survey was created.

The survey was distributed to the 2013 and 2014 Italy Study Abroad program applicants from Stevens and University of Arkansas. The survey was approved by the University of Arkansas Internal Review Board for research on human subjects and sent via email which included a link to the survey. In order to encourage participation in the survey, multiple reminders were sent. Additionally, those students who completed the survey were eligible for prizes drawn at random.

\section{Results}

The results, as shown in this document, were developed from a $22 \%$ response rate.

In order to understand the results, the researchers had to first analyze the demographics of the participants. They found that the majority of the respondents were 2014 participants, upper classmen, and from multiple engineering disciplines (43\% from mechanical engineering). $52 \%$ of these respondents were part of an honors or scholars program, $52 \%$ were female and 55\% have traveled abroad prior to applying. Since the survey was sent to a targeted group, the researchers knew it would not match demographic data for either institution. 
The main questions from the survey were block questions 7 through 10 . These questions were asked to gain insight as to why the engineering student chose to apply to the program with regards to personal growth, ease of being part of program, hope to gain, and timing. These questions used a 5 point Likert-type scale. Any question with a mean greater than 4 was considered important. A mean of 3 was indifferent while less than 3 was unimportant.

Block question 7 on personal growth showed that the respondents wanted to study abroad to acquire a new/different perspective on global issues, expand world view, experience another culture, experience the allure of international travel, enhance overall academic experience, enhance employment opportunities and for personal growth. This is consistent with previous research and shows that the same aspects apply to engineering students. ${ }^{1,2,8}$

Most questions within this block were ranked as very or extremely important with a mean of 4 or higher. $41 \%$ of the respondents ranked assisting with learning a foreign language as either important or unimportant. This is reasonable since the academic course is taught in English. The most interesting finding was the lowest ranked question regarding being the last study abroad opportunity available before graduation. This question had a mean of 3.17 with the largest standard deviation of 1.54 . This is interesting because program participants had to be juniors or seniors to apply. All responses are seen in table 5 below.

\begin{tabular}{|c|c|c|c|c|c|c|}
\hline Question & $\begin{array}{l}\text { Not at all } \\
\text { Important }\end{array}$ & $\begin{array}{c}\text { Very } \\
\text { Unimportant }\end{array}$ & $\begin{array}{l}\text { Nelther } \\
\text { Important } \\
\text { nor } \\
\text { Unimportant }\end{array}$ & $\begin{array}{c}\text { Very } \\
\text { Important }\end{array}$ & $\begin{array}{l}\text { Extremely } \\
\text { Important }\end{array}$ & Mean \\
\hline To improve network \& form valuable contacts & 0 & 0 & 8 & 8 & 7 & 3.96 \\
\hline To acquire new/different perspective on global issues & 0 & 0 & 2 & 4 & 17 & 4.65 \\
\hline To expand your world view & 0 & 0 & 0 & 4 & 19 & 4.83 \\
\hline To experience another culture/country & 0 & 0 & 1 & 3 & 19 & 4.78 \\
\hline To experience the allure of international travel & 0 & 0 & 0 & 11 & 12 & 4.52 \\
\hline To assist with learning a foreign language & 1 & 1 & 9 & 5 & 6 & 3.64 \\
\hline To enhance your degree (improve academic credentials) & 0 & 1 & 3 & 5 & 14 & 4.39 \\
\hline $\begin{array}{l}\text { To enhance employment opportunities (gain competitive } \\
\text { edge) }\end{array}$ & 0 & 0 & 3 & 9 & 10 & 4.32 \\
\hline For own personal growth & 0 & 0 & 0 & 4 & 18 & 4.82 \\
\hline $\begin{array}{l}\text { The last Study Abroad opportunity available before } \\
\text { graduation, so why not apply }\end{array}$ & 4 & 2 & 4 & 3 & 5 & 3.17 \\
\hline Other (please specify) & 4 & 0 & 0 & 1 & 2 & 2.57 \\
\hline
\end{tabular}

\section{Table 5: Question 7 responses}

The second block question, question 8 as seen in table 6 , was about the effect of ease in applying. Only three questions had a mean above a 4 . These questions were about the convenience of the dates of the program, degree credit, and course in English. This infers that students want study abroad programs that have convenient dates, courses they know will count towards their degree, and courses in the same language as their other courses. 


\begin{tabular}{|c|c|c|c|c|c|c|}
\hline Question & $\begin{array}{l}\text { Not at all } \\
\text { Important }\end{array}$ & $\begin{array}{c}\text { Very } \\
\text { Unimportant }\end{array}$ & $\begin{array}{c}\text { Neither } \\
\text { Important } \\
\text { nor } \\
\text { Unimportant }\end{array}$ & $\begin{array}{l}\text { Very } \\
\text { Important }\end{array}$ & $\begin{array}{l}\text { Extremely } \\
\text { Important }\end{array}$ & Mean \\
\hline Ease of not having to find your own study abroad opportunity & 4 & 2 & 5 & 8 & 4 & 3.26 \\
\hline Ease in signing up, registering, enrolling & 2 & 1 & 2 & 13 & 5 & 3.78 \\
\hline Monetary aspects were easy/easier than other opportunities & 2 & 2 & 11 & 3 & 5 & 3.30 \\
\hline Dates of the trip were convenient/ more convenient than others & 1 & 0 & 2 & 7 & 12 & 4.32 \\
\hline $\begin{array}{l}\text { Ease of knowing the course was already accepted as } \\
\text { Stevens/UofA credit }\end{array}$ & 2 & 0 & 1 & 8 & 12 & 4.22 \\
\hline Ease of traveling with a group (i.e. not alone) & 1 & 3 & 6 & 7 & 6 & 3.61 \\
\hline Ease of staying in a hotel with others you know & 2 & 3 & 9 & 4 & 5 & 3.30 \\
\hline Ease of taking a class in English as a study abroad option & 0 & 0 & 5 & 6 & 12 & 4.30 \\
\hline Other (please specify) & 2 & 0 & 3 & 1 & 1 & 2.86 \\
\hline
\end{tabular}

Table 6: Question 8 responses

Block question 9 was very similar to block question 7 and produced the expected results consistent with other research. All questions resulted with a mean above 4, as seen in table 7 .

\begin{tabular}{|c|c|c|c|c|c|c|}
\hline Question & $\begin{array}{l}\text { Not at all } \\
\text { Important }\end{array}$ & $\begin{array}{c}\text { Very } \\
\text { Unimportant }\end{array}$ & $\begin{array}{c}\text { Iveltiner } \\
\text { Important } \\
\text { nor } \\
\text { Unimportant }\end{array}$ & $\begin{array}{c}\text { Very } \\
\text { Important }\end{array}$ & $\begin{array}{l}\text { Extremely } \\
\text { Important }\end{array}$ & Mean \\
\hline Creative problem solving experience & 0 & 1 & 5 & 7 & 10 & 4.13 \\
\hline Self_confidence/personal growth & 0 & 0 & 2 & 8 & 13 & 4.48 \\
\hline Getting more comfortable with unfamiliar situations & 0 & 0 & 0 & 9 & 14 & 4.61 \\
\hline Adaptability in culturally diverse environments & 0 & 0 & 0 & 8 & 15 & 4.65 \\
\hline Awareness of global economies & 0 & 2 & 1 & 6 & 14 & 4.39 \\
\hline Improved communication skills & 0 & 0 & 1 & 9 & 13 & 4.52 \\
\hline Long lasting international friendships/contacts/network & 0 & 0 & 5 & 11 & 7 & 4.09 \\
\hline Simple knowledge of another culture/language & 0 & 0 & 3 & 10 & 10 & 4.30 \\
\hline Other (please specify) & 3 & 0 & 3 & 0 & 3 & 3.00 \\
\hline
\end{tabular}

Table 7: Question 9 responses

The final block question, question 10, regarded timing of the program with respect to other opportunities. The results of this question showed that respondents felt it was important for the timing of the program to allow for work opportunities. This infers that being able to work and study abroad is critical to engineering students participating in study abroad. All responses can be seen in table 8 below.

\begin{tabular}{|c|c|c|c|c|c|c|}
\hline Question & $\begin{array}{l}\text { Not at all } \\
\text { Important }\end{array}$ & $\begin{array}{c}\text { Very } \\
\text { Unimportant }\end{array}$ & $\begin{array}{c}\text { Iveltier } \\
\text { Important } \\
\text { nor } \\
\text { Unimportant }\end{array}$ & $\begin{array}{c}\text { Very } \\
\text { Important }\end{array}$ & $\begin{array}{l}\text { Extremely } \\
\text { Important }\end{array}$ & Mean \\
\hline $\begin{array}{l}\text { Dates of the trip allowed me to be with my family the remainder } \\
\text { of the summer }\end{array}$ & 3 & 2 & 9 & 4 & 3 & 3.10 \\
\hline Dates of the trip allowed me to work the rest of the summer & 1 & 0 & 2 & 7 & 13 & 4.35 \\
\hline $\begin{array}{l}\text { Dates of the trip allowed me to take other classes the remainder } \\
\text { of the summer }\end{array}$ & 4 & 1 & 5 & 4 & 5 & 3.26 \\
\hline Dates of the trip allowed me to travel the rest of the summer & 4 & 2 & 6 & 4 & 4 & 3.10 \\
\hline Dates of the trip played no role in wanting to attend TG 421 -Italy & 9 & 1 & 5 & 2 & 0 & 2.00 \\
\hline Other (please specify) & 4 & 0 & 1 & 0 & 1 & 2.00 \\
\hline
\end{tabular}

Table 8: Question 10 responses

The final survey question was an open response question on the main reason the engineering student chose to apply to the Italy program. This agreed with experts' findings, but shows which of the many items were critical for successful study abroad opportunities for engineers. This study therefore separates the trivial many from the critical few. Specifically, since engineers are only $5 \%$ of the entire US population, as students they may also have specific/different items that are more important to them choosing study abroad options. ${ }^{6}$ Therefore program content/material, timing, language and credit has to be considered and selected specifically for study abroad opportunities to be effective with engineering students. 


\section{Conclusion}

This study provided a great insight in what made this Italy engineering study abroad program so popular and provided information on how to create additional study abroad experiences that could be popular with engineering students. The major results from this study are summarized below:

- Engineering students hope to gain from studying abroad the same things as other students

○ Gain an additional global perspective/experience,

- Enhance their academic experience to gain a competitive edge

- Enhance employment opportunities

- Engineering students want programs offered that uses the same spoken language as their current courses

- Engineering students want programs that they know the courses will count towards their degree

- The timing of a program has a large impact on participation since engineering students want to take advantage of work opportunities.

\section{Reference}

1. Berdan, Stacie Nevadomski, Why Study Abroad?”, Huffington Post, October 10, 2013, http://www.huffingonpost.com/stacie-nevadomski-berdan/why-study-abroad_b_4067124.html

2. Dwyer, Mary M, and Peters, Courtney K, "The Benefits of Study Abroad", 2012, http://www.transitionsabroad.com/publications/magazine/0403/benefits_study_abroad.shtml

3. Engineering Accreditation Commission, Criteria for Accrediting Engineering Programs. Baltimore, MD: ABET, 2012.

4. Goodman, Allan E, "Study Abroad Cultivates Global Leadership", Diplomatic Courier, Jan/Feb, 2103.

5. Institute of International Education, "Open Doors 2011: Study Abroad by U.S. Students Rose in 2009/10 with More Students Going to Less Traditional Destinations", http://www.iie.org/WhoWe-Are/News-and-Events/Press-Center/Press-Releases/2011/2011-11-14-Open-Doors-StudyAbroad\#.UrSSaI1c78A, accessed December 19, 2013.

6. Mather, Mark and Lavery, Diana, "U.S. Science and Engineering Labor Force Stalls, but Trends Vary Across States", Population Reference Bureau, http://www.prb.org/Publications/Articles/2012/scientists-engineers.aspx, accessed January 4, 2014

7. National Academy of Engineering, Educating the Engineer of 2020:Adopting Engineering Education to the New Century, Washington, D.C.: The National Academies Press, 2005.Northwestern University Study Abroad Office, Why Study Abroad, http://www.northwestern.edu/studyabroad/prospective-students/why-study-abroad.html

8. SIT Study Abroad - A Program of World Learning, http://www.sit.edu/studyabroad/1050.htm

9. Specking, Eric; Abel, Kate D; Needy, Kim L.; "Comparing Study Abroad Interest Between Universities", ASEE Annual Conference, June 2013.

10. Vistawide, http://www.vistawide.com/studyabroad/why_study abroad.htm 